\title{
Evaluaiton of Some Imported Wild Cane Genotypes Imported from USA Under Egyptian Conditions
}

\author{
Gaber, A.A. and M.F. Abo El-Fatth ${ }^{1}$
}

\begin{abstract}
Eighteen wild American ENTRIES GENOTYPES of cane and two noble varieties of sugarcane were planted at the end of March in the experimental farm of El-Sabahia Research Station, Alexandria, Egypt during 2003/2004, $\mathbf{2 0 0 4 / 2 0 0 5}$ and $2005 / 2006$ seasons in three replication for evaluation.

Ammonium nitrate was added at the rate of $40 \mathrm{~kg}$ per feddan. irrigation practices were applied at 10-15 days intervals through the growing season except August and September were at 3-5 days intervals.

All their practices were carried out in a similar manner whenever possible.

The results showed that the flowering, the crossing dates and number of seedlings varied for cultivars genotypes and seasons. It could be concluded that the differences among agronomic characters for the four wild studies varieties were highly significant in the most studied characters. "Hinds special" variety proofed to be superior to other wild varieties.
\end{abstract}

\section{INTRODUCTION}

Sugarcane was spread to Persia and then to Egypt through Arab invasions. It is known to be one of the oldest cultivated plants in the world, and is grown commercially in the tropical and subtropical regions. It is the formest crop, where adequate environmental conditions for the crop prevail.

In Egypt, the imported varieties of sugarcane is the only source of sugar up to 1970 A.D. It is grown extensively in Upper Egypt. After the previous date, the production of sugar did not overcome the consumption. This induce the Egyptian investigators to search for other methods and crops to cover the gap between the production and consumption.

Now, the gap between production $(1,772,000$ tons) and consumption $(2,600,000$ tons $)$ was 828,000 tons. The ratio of sufficient was $68.2 \%$.

To overcome the gap between the consumption and production, the Egyptian investigators studied induction factors which increase the crop such as new varieties, cultural methods, environmental conditions, control of the infestation of insects and diseases, flowering induction for germplasm and crossing of the flowering varieties to produce progenies.
The present work was designed to study the behaviour of some wild cane American genotypes in order to crossing these varieties with the local varieties for economical characters under Sabahia Research Station, Alexandria, Egypt.

\section{MATERIALS AND METHODS}

Eighteen wild American genotypes of cane and two noble varieties of sugar cane were planted at the experimental farm of El-Sabahia Research Station, Alexandria, Egypt during 2003/2004, 2004/2005 and 2005/2006 seasons. The experimental design was complete randomized blocks with three replications. Cane seed cuttings were planted in one and half row method at the end of March 2003, 2004 and 2005 seasons. Each variety was cultivated in two ridges. The length of ridge was $5 \mathrm{~m}$. Ridging took place from east to west, with a distance of $125 \mathrm{~cm}$ between every two ridges. Ammonium nitrate was added at the ratio of 40 $\mathrm{kg}$ per feddan. Irrigation practices were applied to 10-15 days intervals through the growing seasons with the exception of August and September were at 3-5 days intervals. Samples were taken from the four varieties Hinds Special, S.E.S..90, Saccharum spontaneum, and U.S. 57-118-4, respectively. Three plants were chopped from each plot at the end of flowering period at random and determined within and between plants as follows in the plant crop: Stalk length and width per $\mathrm{cm}$., tillers number, internodes length and number, leaf length, width and number, and Total Soluble Solids. The stalk length was taken by measuring the distance between soil surface and dewlap (top of stem) with tapeline. The internodes length and leaf width were measured by tapeline. Stalk diameter was taken by verneir calipers. Total Soluble Solids were determined by hand refractometer. Internodes, leaves and tillers number were counted.

After the selection of a given varieties, the average data of the four varieties (Hinds Special, S.E.S.90, Saccharum spontaneum and U.S.57-118-4) for the preceding seasons were statistically analysed according to Snedecor (1969).

The full flowering dates were recorded in plant crop, first and second ratoon in the studied varieties. The crossing were done between G.T.54-9 and C.P.84-

\footnotetext{
${ }^{1}$ Sugar Crops Research Institute, Agriculture Research Centre, Giza, Egypt.

Received Febuary10, 2009, Accepted March30, 2009
} 
226 varieties and wild varieties U.S.57-118-4, and S.E.S.90, however, the other varieties the crossing were open pollination.

After seed harvesting, it is collected and were sown in 5 pots. Each pot was contained 100 seeds. The seedling numbers were counted.

\section{RESULTS AND DISCUSSIONS}

The tabulated data in Table (2) clear that the flowering dates varied among cultivars and ratoons. These variations were due to the growth vigour of stalk and interaction between the planted genotypes and environmental conditions (Table 1). Also, Table (2) indicates average of wild American sugarcane crosses (open pollination) during 2003/2004, 2004/2005 and 2005/2006 seasons, respectively.

Table 1. Temperature degrees and relative humidity from 2003 to 2006 seasons at Sabahia Research Station at Alexandria, Egypt

\begin{tabular}{|c|c|c|c|c|c|c|c|c|c|}
\hline \multirow{3}{*}{ No. } & \multirow{3}{*}{ Month } & \multicolumn{4}{|c|}{ Temperature degrees } & \multicolumn{4}{|c|}{ Relative humidity } \\
\hline & & \multicolumn{2}{|c|}{ Average of } & \multirow{2}{*}{ Mean } & \multirow{2}{*}{ Range } & \multicolumn{2}{|c|}{ Average of } & \multirow{2}{*}{ Mean } & \multirow{2}{*}{ Range } \\
\hline & & Max. & Min. & & & Max. & Min. & & \\
\hline 1 & January 2003 & 21.5 & 9.8 & 15.6 & 11.7 & 96.0 & 55.0 & 76.0 & 41.0 \\
\hline 2 & February & 23.8 & 12.2 & 18.3 & 11.6 & 99.0 & 72.0 & 75.0 & 27.0 \\
\hline 3 & March & 20.1 & 9.3 & 14.7 & 10.8 & 97.0 & 57.0 & 77.0 & 40.0 \\
\hline 4 & April & 25.8 & 13.2 & 19.5 & 12.6 & 96.0 & 46.0 & 71.0 & 50.0 \\
\hline 5 & May & 30.1 & 16.8 & 23.5 & 13.3 & 98.0 & 56.0 & 77.0 & 42.0 \\
\hline 6 & June & 31.9 & 19.2 & 25.6 & 12.7 & 100.0 & 58.0 & 79.0 & 42.0 \\
\hline 7 & July & 32.8 & 23.3 & 28.0 & 19.5 & 96.0 & 62.0 & 79.0 & 34.0 \\
\hline 8 & August & 40.3 & 22.8 & 31.6 & 17.5 & 98.6 & 66.2 & 42.2 & 32.4 \\
\hline 9 & September & 32.3 & 20.3 & 26.3 & 12.0 & 96.0 & 56.0 & 76.0 & 40.0 \\
\hline 10 & October & 31.7 & 18.1 & 24.9 & 13.6 & 100.0 & 50.0 & 75.0 & 50.0 \\
\hline 11 & November & 23.7 & 12.0 & 17.9 & 11.7 & 100.0 & 82.0 & 91.0 & 18.0 \\
\hline 12 & December & 21.2 & 10.6 & 15.9 & 10.6 & 98.0 & 61.0 & 79.0 & 37.0 \\
\hline 13 & January 2004 & 17.9 & 7.8 & 13.3 & 10.1 & 98.0 & 66.0 & 32.0 & 32.0 \\
\hline 14 & February & 24.9 & 13.4 & 19.2 & 11.5 & 100.0 & 73.0 & 87.0 & 27.0 \\
\hline 15 & March & 23.9 & 11.2 & 17.3 & 12.7 & 99.0 & 58.0 & 78.0 & 41.0 \\
\hline 16 & April & 26.0 & 12.0 & 19.2 & 14.0 & 99.0 & 51.0 & 75.0 & 28.0 \\
\hline 17 & May & 28.1 & 16.5 & 22.3 & 11.6 & 98.0 & 50.0 & 74.0 & 48.0 \\
\hline 18 & June & 30.1 & 19.4 & 24.8 & 10.7 & 99.0 & 62.0 & 81.0 & 37.0 \\
\hline 19 & July & 33.0 & 22.1 & 27.6 & 10.9 & 99.0 & 61.0 & 80.0 & 38.0 \\
\hline 20 & August & 33.3 & 22.0 & 27.7 & 11.3 & 99.0 & 64.0 & 81.0 & 35.0 \\
\hline 21 & September & 31.5 & 19.6 & 25.6 & 11.9 & 99.0 & 58.0 & 78.0 & 41.0 \\
\hline 22 & October & 31.4 & 17.3 & 24.3 & 14.1 & 89.0 & 37.0 & 63.0 & 52.0 \\
\hline 23 & November & 26.0 & 15.2 & 20.6 & 10.8 & 99.0 & 62.0 & 80.0 & 37.0 \\
\hline 24 & December & 20.1 & 10.5 & 15.8 & 9.6 & 98.0 & 60.0 & 78.0 & 38.0 \\
\hline 25 & January 2005 & 16.7 & 6.6 & 12.3 & 10.1 & 99.0 & 69.0 & 82.0 & 30.0 \\
\hline 26 & February & 19.6 & 8.9 & 14.3 & 10.7 & 98.0 & 67.0 & 82.0 & 31.0 \\
\hline 27 & March & 21.8 & 12.2 & 17.1 & 9.6 & 95.0 & 57.0 & 76.0 & 38.0 \\
\hline 28 & April & 23.7 & 13.3 & 18.5 & 10.4 & 99.0 & 56.0 & 77.0 & 43.0 \\
\hline 29 & May & 28.5 & 15.9 & 22.2 & 12.6 & 99.0 & 57.0 & 78.0 & 42.0 \\
\hline 30 & June & 30.1 & 19.5 & 24.8 & 10.6 & 99.0 & 64.0 & 82.0 & 35.0 \\
\hline 31 & July & 32.3 & 21.5 & 26.9 & 10.8 & 100.0 & 64.0 & 82.0 & 36.0 \\
\hline 32 & August & 32.8 & 23.1 & 28.0 & 9.7 & 89.0 & 58.0 & 73.0 & 31.0 \\
\hline 33 & September & 33.1 & 20.7 & 26.7 & 12.4 & 97.0 & 57.0 & 77.0 & 40.0 \\
\hline 34 & October & 27.7 & 17.4 & 22.5 & 10.3 & 96.0 & 61.0 & 78.0 & 35.0 \\
\hline 35 & November & 24.0 & 13.3 & 18.6 & 10.7 & 97.0 & 59.0 & 78.0 & 38.0 \\
\hline 36 & December & 20.0 & 10.0 & 17.9 & 10.0 & 97.8 & 60.0 & 78.8 & 37.8 \\
\hline 37 & January 2006 & 18.1 & 8.8 & 13.4 & 9.3 & 100.0 & 73.0 & 87.0 & 17.0 \\
\hline 38 & February & 20.1 & 8.8 & 14.5 & 11.3 & 98.0 & 67.0 & 82.0 & 31.0 \\
\hline 39 & March & 22.3 & 11.3 & 16.8 & 11.0 & 99.0 & 53.0 & 76.0 & 46.0 \\
\hline 40 & April & 26.2 & 14.5 & 20.3 & 11.8 & 98.1 & 56.0 & 77.0 & 42.1 \\
\hline 41 & May & 27.9 & 14.8 & 21.4 & 13.1 & 100.0 & 61.0 & 80.0 & 38.0 \\
\hline 42 & June & 31.1 & 19.9 & 25.5 & 11.2 & 100.0 & 62.0 & 81.0 & 38.0 \\
\hline
\end{tabular}


Table 2. Average full flowering dates of eighteen wild cane American varieties, two varieties of sugarcane and crossing of the prior varieties during plant crop, first and second ratoon for 2003/2004, 2004/2005 and 2005/2006 seasons at EI Sabahia Res. St., Alex., Egypt

\begin{tabular}{|c|c|c|c|c|c|c|c|c|}
\hline & \multirow[b]{2}{*}{ Cultivars } & \multicolumn{3}{|c|}{$\begin{array}{c}\text { Period per days from sowing } \\
\text { to full flowering }\end{array}$} & \multicolumn{4}{|c|}{ Crossing } \\
\hline & & $\begin{array}{l}\text { Plant } \\
\text { Crop }\end{array}$ & $\begin{array}{c}\text { First } \\
\text { Ratoon }\end{array}$ & $\begin{array}{l}\text { Second } \\
\text { Ratoon }\end{array}$ & & $\begin{array}{l}\text { Pots } \\
\text { No. }\end{array}$ & $\begin{array}{c}\text { Seedlin } \\
\text { g } \\
\text { No. } \\
\end{array}$ & $\begin{array}{l}\text { Sel- } \\
\text { ting }\end{array}$ \\
\hline 1 & Hindo Special & 220 & 282 & 305 & Hinds Special X? & 5 & 7 & - \\
\hline 2 & S.E.S.90 & 228 & 228 & 282 & S.E.S.90 X? & 5 & 12 & - \\
\hline 3 & Saccharum spontaneum & 339 & 345 & 397 & Saccharum Spont. X? & 5 & 5 & - \\
\hline 4 & US.57-118-4 & 228 & 282 & 302 & U.S.57-118-4 X? & 5 & 8 & - \\
\hline 5 & N.G.21-21 & & \multirow{18}{*}{ 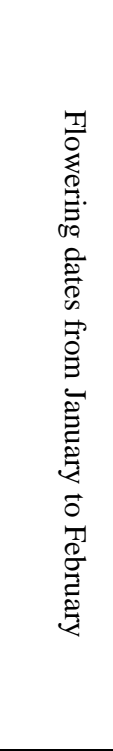 } & & N.G.21-21 X? & 5 & 8 & - \\
\hline 6 & IK76-35 & & & & IK76-35 X? & 5 & 6 & - \\
\hline 7 & IN84-24 & & & & IN84-24 X? & 5 & 3 & - \\
\hline 8 & I.J.76-319 & & & & I.J.76-319 X? & 5 & 9 & - \\
\hline 9 & Malagache & & & & Malagache X? & 5 & 11 & - \\
\hline 10 & N.G.51-127 & & & & N.G.51-127 X? & 5 & 3 & - \\
\hline 11 & PHIL & & & & PHIL X? & 5 & 3 & - \\
\hline 12 & OLOANG & & & & OLOANG X? & 5 & 4 & - \\
\hline 13 & S.E.S.323 & & & & S.E.S.323 X? & 5 & 3 & - \\
\hline 14 & S.E. 220 & & & & S.E.S.220 X? & 5 & 15 & - \\
\hline 15 & IN84-126 & & & & IN84-125 X? & 5 & 6 & - \\
\hline 16 & IND81-59 & & & & IND81-59 X? & 5 & 6 & - \\
\hline 17 & IND81-46 & & & & IND81-46 X? & 5 & 6 & - \\
\hline 18 & IND22 & & & & IND22 X? & 5 & 6 & - \\
\hline \multirow[t]{2}{*}{19} & CP.84-226 & & & & C.P.84-226 X U.S.57-118.4 & 5 & - & - \\
\hline & CP.84-226 & & & & C.P.84-226 X S.E S.90 & 5 & - & - \\
\hline \multirow[t]{2}{*}{20} & G.T.54-9 & & & & G.T.54-9 X U.S.57-118-4 & 5 & - & - \\
\hline & G.T.54-9 & & & & G.T.54-9 X S.E.S.90 & 5 & - & - \\
\hline
\end{tabular}

The crossing dates varied with the variation of the varieties and seasons. The seedling number in pots after two months from sowing varied with the variation of varieties and seasons. These results are in agreement with those obtained by Chu and Serapion (1971), Rao et al. (1973), Nour et al. (1977 \& 1984), Gaber et al. (1984, a, b \& c), Gaber et al. (1992), Gaber \& Rashwan (1993), Abou El-Fatth et al. (1994), Abou El-Fatth and Gaber (2004), Gaber and Abou El-Fatth (2004) and Gaber et al. (2007).

Table (3) shows the analysis of variance between four wild American varieties of sugarcane (Hinds special, S.E.S.90, Saccharum spontaneum, and U.S.57118-4) in Sabahia Research Station during 2003/2004, $2004 / 2005$ and $2005 / 2006$. It is clear that the differences between the certain varieties were highly significant in most studied characters, but these differences within the varieties (between plants) were not significant (Table 5). However, Table (4) indicates that Hinds Special was superior to the other varieties (S.E.S.90, Saccharum spontaneum and U.S.57-118-4).
These results were agreement with those obtained by Gaber and Abou El-Fatth (2004) (Figures 1, 2 and $3)$.

Regarding to Table (1) shows the temperature degrees and relative humidity were differed from one month to another, one day to other and from one season to another. It is due to the variation of environmental conditions. Subsequently, it is referred to the prior varieties. Beside the genetic variations and the interaction between genotypes and climatic conditions.

In this aspect it could be referred to Humbert (1968), Gaber et al. 1984c), Gaber and Rashwan (1990), Gaber et al. (1992), Gaber and Rashwan (1993), Gaber and Abo El-Fatth (2004), Abo El-Fatth and Gaber (2004), and Gaber et al. (2007) who found that sugarcane flowering vary tremendously due to many factors as follows: variable soil fertility, use of fertilizers, cultural practices, varieties used, irrigation, control of weeds, pests and diseases, and other factors

In Egypt sugarcane flowering is considered to be new direction in cane breeding programme. The above mentioned data agree with those reported by Breet 1950 
and Climents \& Awado (1964) who reported that the optimum conditions for floral initiation and tasselling in sugarcane.

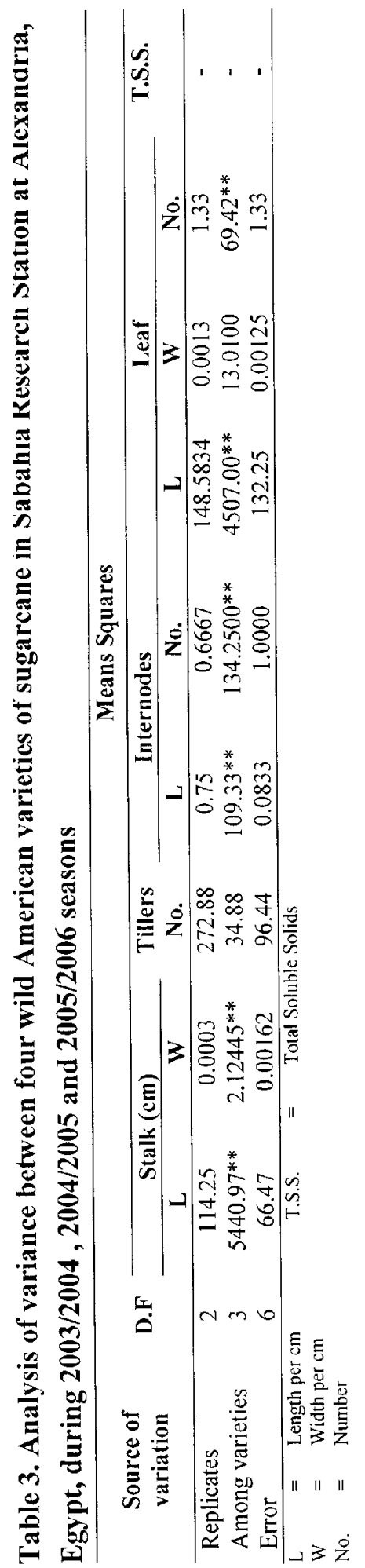

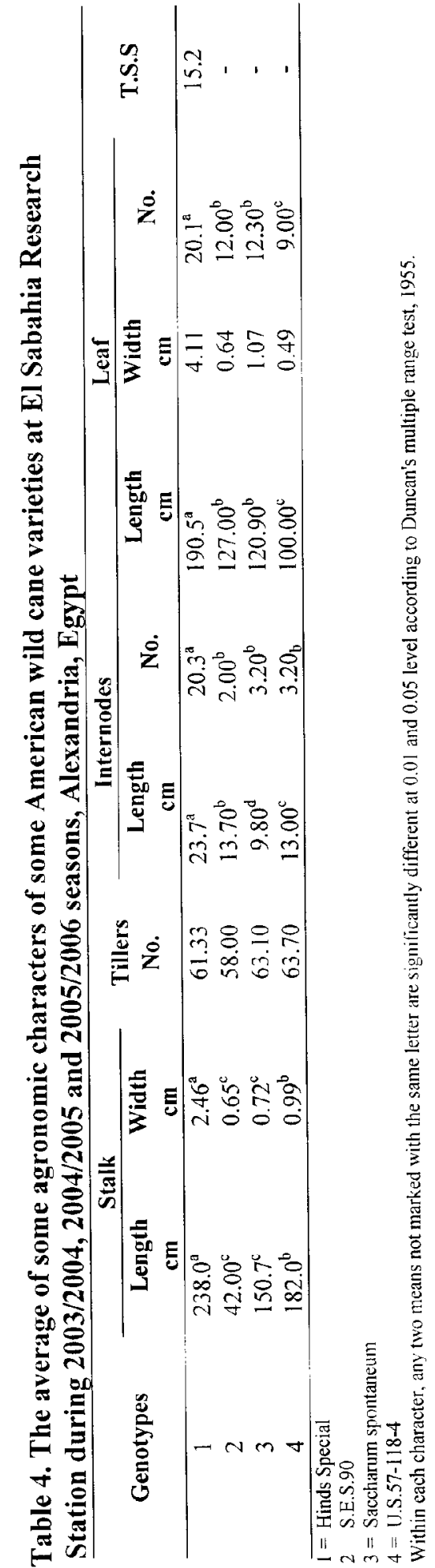




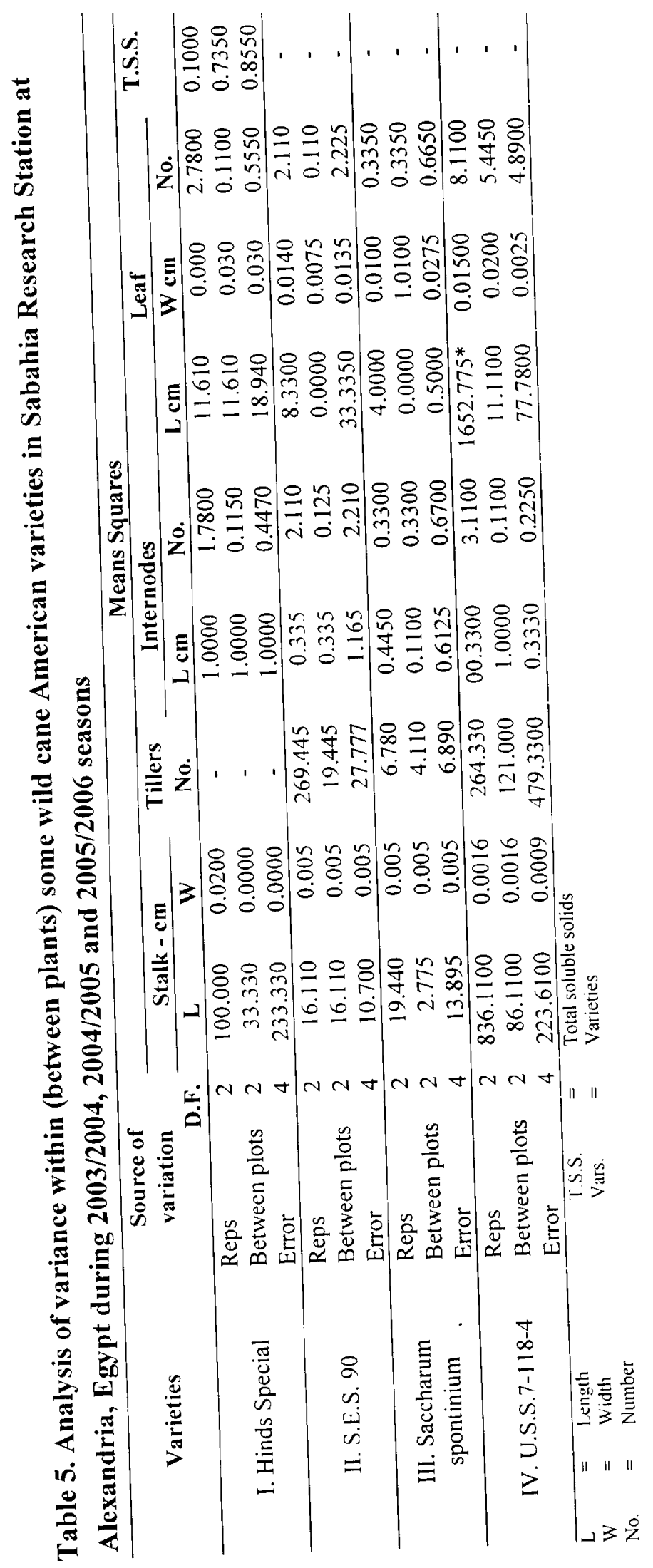


$\mathrm{cm}$

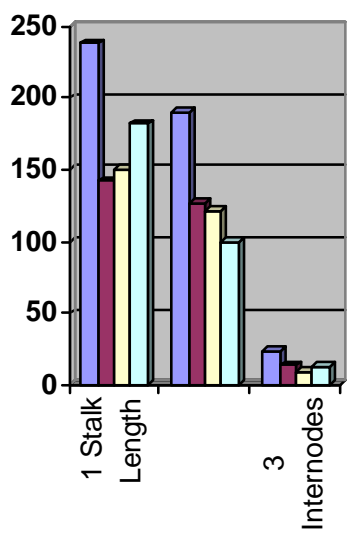

$\square$ Hinds Special

口S.ES.90

$\square$ Saccharum spontaneum $\square$ U.S.57-118-4

Fig. 1. Stalk, leaf and Internodes length

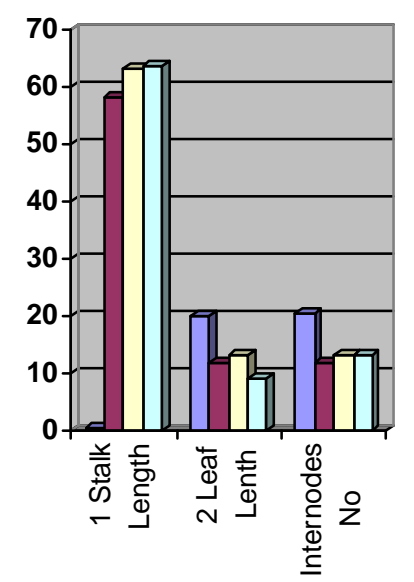

$\square$ Hinds Special $\square$ S.ES.90

$\square$ Saccharum spontaneum 口 U.S.57-118-4

Fig. 2. Tillers, leaf and internodes number $\mathrm{cm}$
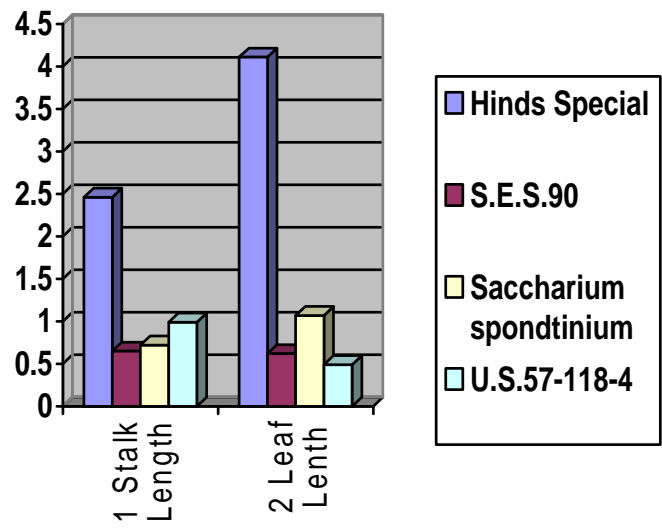

Fig. 3. Stalk and leaf width of four cane varieties 
It was concluded from Rao and Kirshnumurthy (1968) that the conditions of temperature, humidity and day length in Alexandria, Egypt is ideal for floral induction (Rao et al., 1973).

In Egypt the trials of sugarcane flowering were succeeded with controlling of irrigations regime and nitrogen fertilization at Alexandria (Rao et al., 1973, Nour et al. 1977 and Allam et al., 1977).

The varieties of sugarcane differ widely in the physiological characters, especially the occurrence of flowering under Egyptian conditions (Gaber et al., 1981a).

The end product of this study that to improve the local varieties, we must to select the sugarcane varieties which highly in yield and sucrose content, and crossing these varieties for the economic characters of wild varieties as tillering and resistance for diseases.

\section{REFERENCES}

(1) Abou El-Fatth, M.F.; A.A. Gaber; Y.H.M. Tawfic and N.M.A. El-Talkhawy (1994). Effect of sowing dates on flowering and seed setting of some sugarcane varieties at Alexandria. Alex. Sci. Exch. Vol. 15, pp. 105-125.

(2) Abou El-Fatth, M.F. and A.A. Gaber (2004). Effect of ratooning on on flowering and seed setting on some sugarcane varieties at Alexandria, Egypt. Alex. Sci. Exch. Vol. 25, No. 4, pp. 765-772.

(3) Alexander, A.G. (1973). Sugarcane physiology, flowering A. Comprehensive study of Saccharum source to sink system. El-Sevier Scientific Publishing Co., London, England, pp. 523-572.

(4) Allam, A.I.; A.H. Nour and T.A. Fayed (1977). The flowering behaviour of latitudinally displaced sugarcane varieties. Proc. ISSCT, XVI 283-290.

(5) Annual Conference of Egyptian Society Sugar Technologists, 2008, 39, pp. 9-13.

(6) Brett, P.G. (1950). Flowering and pollen fertility in relation to sugarcane breeding in Natal. Proc. ISSCT, 7, 43-56

(7) Chu, T.L. and J.L. Serapion (1971). Flower initiation and tassel emergence in sugarcane. J. Agric. Univ., P.R. 55(I): 101-115.

(8) Climents, H.F. and M. Awado (1964). Factors effecting the flowering of sugarcane. Indian J. Sugarcane Research and Development, Vol. 8: 140-159.

(9) Gaber, A.A.; H.A. Mesbah; A.H. Nour and M.A. Abdel Rassol (1981a). Correlation between yield and some morphological, physiological, chemical characters and borer infestations in thirty four varieties of sugarcane at Alexandria. Agric. Res. Rev. Vol. 59, No. (8): 99-112.
(10) Gaber, A.A.; T.M. Fayed; T.A. Abd El-Latif and M.A. Farag, (1984a). Effect of some growth regulators on flowering habit and some economical characters on sugarcane. Second Conf. ARC. Giza 9-11 April, X I2.

(11) Gaber, A.A.; R.A. Eskander and M.A. Farg (1984b). Relationship between flowering and some economic characters of nine sugarcane varieties. Second Conf. ARC. Giza 9-11 April, X 14.

(12) Gaber A.A.; S.H. Farrag; M.F. Abou El-Fatth and S.G., Ibrahim (1984c). Effect of locations and environmental conditions on flowering induction in sugarcane. Second Conf. ARC. Giza 9-11 April, X 15.

(13) Gaber A.A. and Laila, M.A. Rashwan (1990). Effect of temperature and relative humidity on tillering and borers infestation of some sugarcane varieties at Alexandria. Com. In Sci. \& Dev. Res., Vol. 31: 1-12.

(14) Gaber, A.A.; M.F., Abou El-Fatth and A.H. Nour (1992). Flowering behaviour of some sugarcane varieties at Alexandria. Egypt Alex. Sci., Exch., vol. 13, No. 4: 831844.

(15) Gaber, A.A. and Laila, M.A. Rashwan (1993). Effect of varietal, geographical sources on yield, yield components, agronomic characters and borers infestations of some sugarcane varieties at Alexandria, Egypt Com. In Sci. \& Dev. Res., Vol. 42, No. 653, pp. 149-164.

(16) Gaber, A.A. and M.F. Abou El-Fatth (2004). Crossing of some sugarcane varieties under the Egyptian conditions. Alex. Sci. Exch., Vol. 25, No. 4, pp. 757-764.

(17) Gaber, A.A., Safaa, S.M. El-Sayed and M.F. Abou ElFatth (2007). Effect of drowning on flowering and seed setting of some sugarcane varieties at Alexandria, Egypt. Alex. Sci. Exch., Vol. 28, No. 1, pp. 9.

(18) Humbert, R.O. (1968). The growing of sugarcane

(19) Nour, A.H.; A.A. Gaber, J.T. Rao and T.M. Elamary (1977). Flowering of sugarcane and breeding prospects in Egypt. Agric. Res. Rev., pp. 77-85.

(20) Nour, A.H.; A.A. Gaber, N.A. El Talkhawy and Y.H.M. Tafik (1984). Two seasons of flowering in sugarcane under Egyptian conditions. Second Conf. ARC. Giza 911 April, X 13.

(21) Rao, J.T. and T.N. Krishnumurthy, (1968). Accelerating genetic improvement in sugar cane. Ind. Jour. Of Gene. And Plant Breeding 28(A), 88-96.

(22) Rao, J.T.; A.H. Nour and M.A. El-Manhaly (1973). Flowering of sugarcane in Egypt. Int. Sugar Jour. 75: 241-244.

(23) Snedecor, G.W. (1969). Statistical Methods, $5^{\text {th }}$ Edition, Iowa State Univ. Press, Ames., Iowa, U.S.A.

(24) Stevenson, G.C. (1965). Genetics and Breeding of sugarcane 


\section{الملخص العربي}

\section{تقييم بعض سلالات قصب السكر البرية المستوردة من الولايات المتحدة الأمريكية تحت الظروف المصرية \\ عبد الحميد عبد الحميد جابر، محمد فوزى أبو الفتح}

تم زراعة ثمانية عشر سلالة برية من القصب البرى مستوردة من 1- اختلفت السلالات فيما بينها فن تواريخ التزهير والتهجين

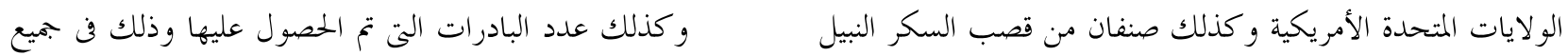

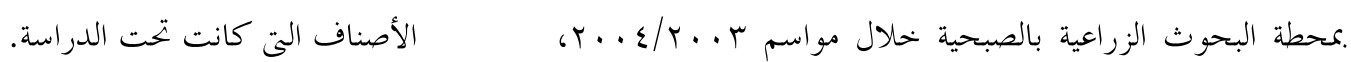

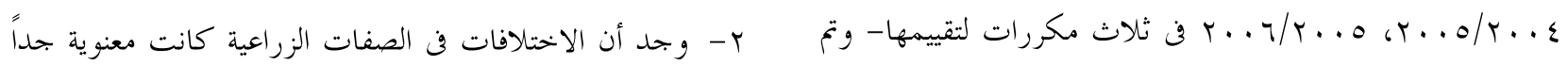

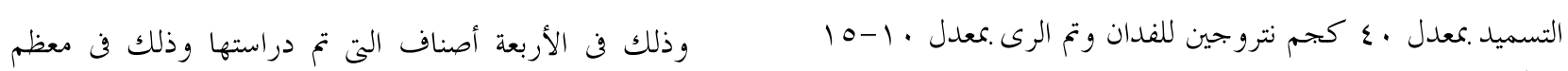

$$
\text { يوماً خحلال موسم النمو ما عدا شهرى أغسطس وسبتمبر فكانت الصفات المدروسة. }
$$

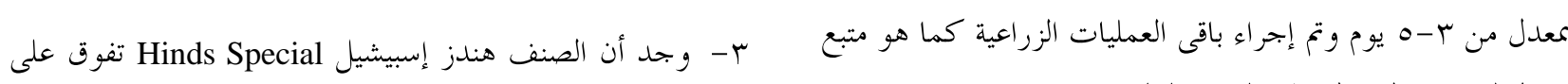

$$
\text { باقى الأصناف. }
$$

فن المنطقة وتم الحصول على النتائج التالية:- 